\title{
1111 センサ情報を用いた定性推論の暧昧性の緩和
}

\section{A solution of the ambiguity problem of qualitative reasoning using sensor signals}

\author{
横田久幸（岡山大学），正五福明夫（岡山大学）
}

Hisayuki YOKOTA, Okayama University, 3-1-1, Tsushima-Naka, 700-8530 Okayama Akio GOFUKU, Okayama University

KeyWords : multilevel flow modelling, qualitative reasoning, sensar signal, DURASS

\section{1. 緒 言}

著者らは，システムの意図と構造を関連づけてモデル化できる点 から，機能モデリングを応用した大規模プラントの運転員支援情報 生成手法について研究を進めている。これまでに，機能モデリング の一手法である Multilevel Flow Modelling（MFM）[1]を基礎モデルと して用い，プラントに異常が発生した場合の異常原因推定手法[2]や 対応操作候補の基出手法[3]を提案している. これらのうち, 対応操 作候補䆃出手法では, 対灾操作のプラント挙動一の影響を定性推論 によって推定し，回避あるい、緩和したいプラント状態に効果のあ る対応操作候補の尊出老行っている.

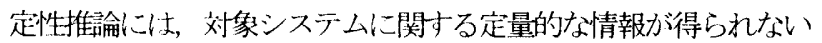
ときでも，既知U情報を論理的に組み合わせて，システムの振る舞 いを枚举できるという特長があるが，「正」の影響と「負」の影響 が1つの推論ノードに波及した場合に，総合的な影響が「正」と

「負」のどちらになるか判断できないという曖昧性の問題がある。 そこで，本研究では，センサ信号を用いて部分的な数值シミュレー ションを行うことによる曖昧性の緩和手法を提案する。

\section{2. センサ情報を用いた影響波及推論}

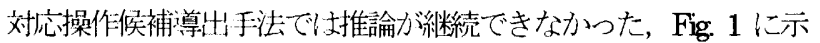
すような複数の影響波及が合流寸る箇所に対して，センサ信号を用 いて部分的な数值シミュレーションにより影響を定量的に評価し， それを定性值に変換して定性的な影響波及推論を継続する。

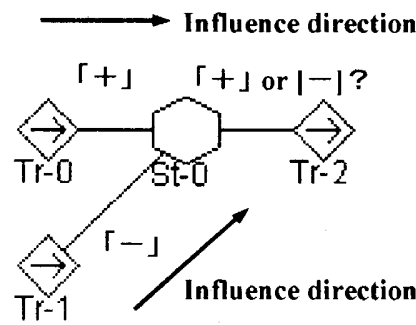

Fig. 1 Problem in qualitative influence propagation

定性推論上部分的な数值シミュレーションを組み合わせることの 利点は，定性推論で行えなからたループや合流部分の推論ができ る.これに対して数值シミュレーションでは, 対象システムに発生 寸る振る舞いの因果関係が計算結果である数值だけからでは把握し にくい，このような計算結果の解釈の困難さを，定性推論の因果説 明能力で補うことができる.

本手法索適用寸るための前提条件は，(のシステムムの举動を数值シ ミュレーションするための数学モデル（数学方程式系）は既知であ る, (b)各数学方程式丈線形時間微分方程式である，(d) 数学モデルに 現れる変数のいくつかはセンサにより観測されている，(d) 数学モデ ルの変数は影響波及推論の基礎となる MFM の機能や目標に 1 対 1 で対応づけられている，(e) 少なくとも数学モデル全体を用いると， システムの挙動を数值シミュレーションにより計算できる，である.

影響波及の合流筒所に対して，その機能や目標に対応寸る変数を 部分的な数值シミュレーションによりセンサ信号を用いて計算する アルゴリズムの概要は以下の通りである.

(1) MFM モデルのノード関係を分析して, 合流箇所の MFM ノー ド（機能または目標）を同定する. (2) MFM ノードと数学モデルの 変数との対応関係から, 合流個所の MFM ノードに対応する変数を 同定寸る. (3) 数学モデルの変数の依存関係を求め[4], それを变数関 連図としてまとめる. (4) 合流箇所の MFM ノードに対応する変数を 数值シミュレーションによりセンサ信号を用いて計算できる最小セ ットの数学方程式系を, 次節で説明する手法によりシステム全体の 数学方程式采力ら選ひ出す。

\section{3. センサ信号を用いて影墰の定性値を計算するための 数学方程式系の導出}

ここでは，数学方程式に現れる変数を，観測変数（センサにより 観測されている変数）亡非観測変数に分類し，さらに，非観測変数 を，(i)影響変数 : 定性的影響を明らかにしたい非観測変数, (ii)末知 変数 : 影響変数以外の非観測変数, (iii)計算变数: 数学方程式采を用 いて観測変数から值を計算できる末知変数，に分類する.これらの 用語を用いて，センサ信号を用いて影響変数を計算する最小セット の方程式系を求めるアルゴリズムを以下に示す.

ここで，最小セットとは数学方程式系に含まれる非観測変数が最 も少なくなることを意味する. これを行うために選択された数学方 程式から構成された数学方程式系を行列方程式 $A x(t)=B$ に変換す る. ここで $x(t)$ は時間 $t$ におうりる非観測変数ベクトル， $B$ は観測変 数と定数からなるべクトルである. そして, 俰数行列 $\mathrm{A} の$ rank 求 めて最小性を評価する.

(1) 影響変数を含む方程式を検索する.

(2) 検索している変数累導出する方程式が複数あるか調へ，複数 あれば(3)一進む。.なければ(5)一進む。

（3）現在の状態を保存して方程式の種類と数を保存する.

(4) 方程式を一選ぶ.

(5) 方程式に含まれている末知変数を末知変数リストに追加する (未知変数リストの初期値は空リスト)

（6） 末知変数リストが空リストであれば(8)へ進み，そうでなけ れば(7)一進さ

（7）末知変数リスト中にある一つの未知変数を計算変数として方 程式を検索し，(2)に戻る.

（8）方程式を行列方程式に変換して rankの計算を行う. 
（9）行列方程式の rankが日観測変数の数より小さければ(10)人， そうでなければ(11)進む.

(10) 行列方程式の rankが今までに求まった数学方程式系の rank より小さいか判別し，大きければ(11)進み，小さければ数 学方程式系を保存才る.

（11）まだ選んでいない方程式が存在するか判別し，存在すれば (12)八進み, 存在しなければ(13)八進む.

（12）検索中心状態を読み込み，(2)に戻る.

(13) 現在保存している数学方程式の組が最小セットの数学方程式 となる.

\section{4. 適用例題}

提案手法を Fig. 3 に構造を示寸DURESS と呼ばれるシステム[5]に 適用した. DURESS で士，ボンプの動作条件(ONOFF)，各バルブの 開度制御およよびザーバのヒータの制御により，2つのリザーバの 水位と温度を制御できる。

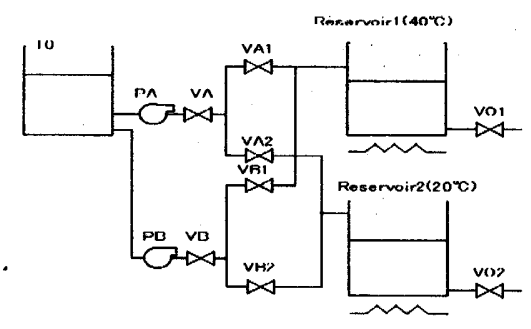

Fig. 2 Composition of DURESS

本適用に执いては, DURESS 全体を数值シミュレーションする 数学各方程式には, DURESS シミュレータ[6]のものを用い, 配管 の流量, 各ヒータの出力, リザーバの水位をセンサにより計測し ているものとした。 また，DURESSに対する MFM モデル（部

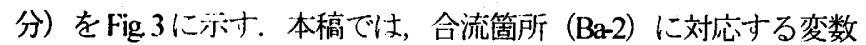
を計算する最小七ットの数学方程式系の導出について説明する.

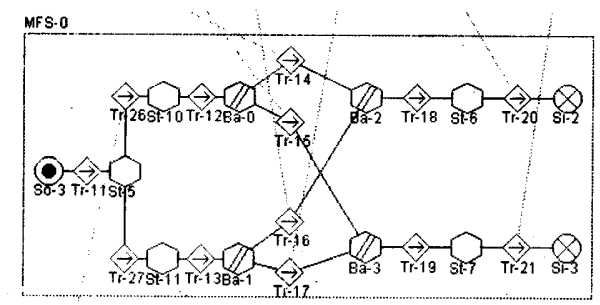

Fig. 3 Part of MFM model for DURESS

$\mathrm{Ba}-2$ を実現するコンポーネント（バルブVAl とVA2からの流れ が合流寸るミキサ部）に関連する数学方程式は，

$$
\begin{aligned}
& q_{R \mid}(t)=q_{\left|A_{1}\right|}(t)+q_{\mid B_{1}}(t) \\
& q_{l \cdot A \mid}(t)=q_{l \cdot A}(t)-q_{l_{A 2}}(t) \\
& q_{R \mid}(t)=a\{W(t)-W(t-1)\}+q_{\mid(t) 1}(t)-b \\
& q_{w o l}(t)=r_{i o l}(t)
\end{aligned}
$$

である. $q$ は流量を, $W$ は水位を, $V$ はバルブの開度を表し $a, b$ は定数である．影響变数は $q_{R 1}(t)$ であり，観測変数は $q_{1 \cdot A}(t)$,

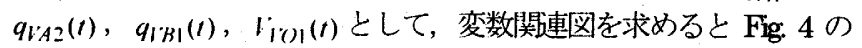
2通りが得られる.

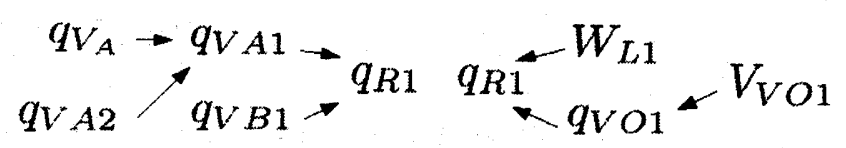

Fig. 4 Relations of variables

そして，センサ信号を用いて影響変数を計算する最小セットの数 学方程式系を導出すると，式(1)(2)，あるいは式(3)(4)からなる数学方 程式系となった. 式(1)(2)で構成される数学方程式系を用いてセンサ 信号から影響変数を計算する. このときVA2, VB1 が故障し $q_{V A 2}(t)$, $q_{|B|}(t)$ が小さくなった場合の影響変数 $q_{R 1}(t)$ を計算すると, Fig. 5 のようになる。20( $q_{R 1}(20)-q_{R 1}(0)=154(\mathrm{~kg} / \mathrm{g})$ となる. したがって定性的な影響は 「十」として影響波及推論を継続すれば良いことがわかる.

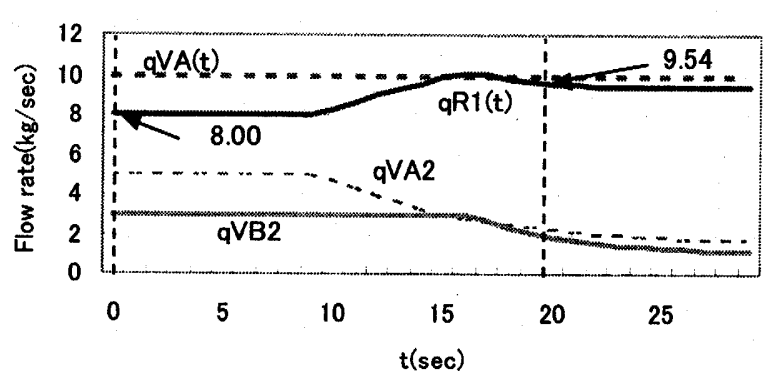

Fig.5 Calculation results of influenced variable

\section{5. 結 䨐}

定性推論の本質的な問題点である曖昧性の緩和手法として, セン サ信号を用いた定性的影響波及推論手法を提案し，そのための，影 響変数を計算する最小セットの数学方程式系の導出アルゴリズムを 述べた．本手法は定性推論のみならずセンサバリデーションのため に, システムの数学方程式が既知である場合に, あるセンサ值を他 のセンサ值から計算するための方程式系を導出する手法としても適 用可能である.

\section{6. 参考文献}

(1) M, Lind : Modeling goals and functions of complex industrial plants ; Applied Artificial Intelligence, Vol. 8, No. 2, pp. 259-283 (1994)

（2）犬塚 圭, 五福 明夫, 田中 豊 : プラントの部分モデル に基づく探索範囲拡大型異常原因推定手法，システム制御 情報学会論文誌, Vol. 16, No. 3，pp101-110（2003）

（3）五福明夫，足立和寛，田中豊 : 機能と挙動に基づくプラ ント異常時対态操作侯補の導出，システム制御情報学会論 文誌, Vol. 11，No. 8, pp. 458-465. (1998)

（4）熟尾 隆：物理法則に基づく外的駆動型因果性の導出, 人工知能学会誌 Vol. 5, No. 4, pp94-103(1990)

(5) Vicente, K. J. : Supporting Operator Problem Solving Through Ecological Interface Design, IEEE Trans.SystMan -Cyber., Vol. SMC-25, No. 4, pp. 529-545, (1995)

(6) http:/www.mie.utoronto.calabs/cel/research/platform/ 